\title{
Explanation of Off Label Use
}

National Cancer Institute

\section{Source}

National Cancer Institute. Explanation of Off Label Use. NCI Thesaurus. Code C92487.

The description of how a product was used that was not according to its approved use for. 